\title{
Phytophthora Species Emerging as Pathogens of Forest Trees
}

\author{
Everett M. Hansen
}

Published online: 3 February 2015

(C) Springer International Publishing AG 2015

\begin{abstract}
Species of Phytophthora are prominent in lists of emerging threats to forest ecosystems. We explore the conditions leading to and the consequences of the emergence of some Phytophthora species from their presumptive coevolved roles in undisturbed forest ecosystems to destructive agents as invasive forest pathogens. Phytophthora species are widespread, relatively abundant, very diverse, and poorly understood in many relatively undisturbed forest ecosystems. Three examples are examined in detail to illustrate the range of pathways to emergence and the varied consequences to forest environments. Phytophthora lateralis causes Port-Orford cedar root disease in western North America and now Europe. Phytophthora ramorum is causing unprecedented mortality in oak and tanoak forests in California, as the cause of sudden oak death, and is killing planted larch in the UK, and Phytophthora cinnamomi kills trees in parts of the world where it has been introduced. Active programs are underway in each case to manage, if not eliminate, their damage. In no case, however, has eradication been achieved. Prevention, by blocking initial introduction, has the highest probability of success.
\end{abstract}

Keywords Indigenous pathogens $\cdot$ Lateralis $\cdot$ Ramorum . Cinnamomi · Disease management · Phytophthora species . Pathogens of forest trees

Forests are plant communities dominated by trees. There are urban forests with street and landscape trees, plantation forests

This article is part of the Topical Collection on Forest Pathology and Entomology

E. M. Hansen $(\bowtie)$

Department of Botany and Plant Pathology, Oregon State University, 1086 Cordley Hall, Corvallis, OR 97333, USA

e-mail: hansene@science.oregonstate.edu intensively managed for timber and other products, and wild forests growing in natural environments. Boreal forests, temperate forests, and tropical forests have unique characteristics, but all are dominated by trees. Forests provide habitat for most of the terrestrial earth's biological diversity and are instrumental in regulating global water and carbon cycles. Yet everywhere they are changing rapidly, with trees under pressure from many forces. Threats range from direct destruction by humans through land use change forced by increasing human populations to the mounting physiological and ecological stresses imposed by changing world climates $[1,2]$.

Plant pathogenic microorganisms, especially species of Phytophthora, are prominent in lists of emerging threats to forest ecosystems [3, 4]. Forests evolved with many herbivorous organisms including many Phytophthora species, and the interrelationships, while dynamic and complex, are usually not threatening to the forest ecosystem [5]. When conditions change, however, as through transport of pathogens or trees to new environments [6] or exposure to new hosts lacking coevolved resistance, or change in the environment itself, forest pathogen dynamics change, often to the detriment of the forest. Previously benign pathogens may become invasive and destructive. In this paper, I explore the conditions leading to and the consequences of the emergence of some Phytophthora species from their presumptive coevolved roles in undisturbed forest ecosystems to destructive agents as invasive forest pathogens.

Phytophthoras are well known as agricultural plant pathogens, causing economic losses in many crops from potatoes to alfalfa [7]. The name derives from the Greek for "plant killer," they are heterotrophic, deriving their nutrition from the enzymatic destruction of living plant cells. Classically, they are especially destructive in poorly drained soils or cool, wet climates (Table 1). These are Oomycetes, algal relatives, and not true fungi (Kingdom Fungi) at all $[8,9 \bullet]$. Despite their unique evolutionary history, however, they grow as filamentous 
Table 1 Some emergent species of Phytophthora and the forest diseases they cause

\begin{tabular}{lllll}
\hline Pathogen & Disease & Host & Region & Disease management \\
\hline P. alni & Collar rot & Alder & & Clean nursery stock \\
P. austrocedrae & Mal del cipres & Austrocedrus & Patagonia & Limit animals in the forest \\
$P$. cinnamomi & Jarrah dieback & Jarrah eucalyptus & Western Australia & Sanitation \\
& Littleleaf disease & Shortleaf pine & SE USA & Change tree species \\
& Ink disease & Chestnut & E. USA and Europe & Limit soil transport \\
P. lateralis & Cedar root disease & Port-Orford cedar & Western North America & Sanitation, avoidance, \\
a. pinifolia & Daño Foliar del Pino & Radiata pine & and Europe & Wait for the weather to change \\
P. pluvialis & Red needle cast & Radiata pine & New Zealand & Resistance?, site selection \\
P. ramorum & Sudden oak death, & Fagaceae, Ericaceae, & Western North America & Quarantine and eradication \\
& ramorum blight & Larix, and more & and Europe &
\end{tabular}

hyphae and reproduce by spores, like fungi. They are water molds dispersing and infecting plants by motile zoospores and surviving dry conditions as thick-walled chlamydospores or oospores. Phytophthoras are plant pathogens, although they vary in strategy of pathogenesis from colonizers of fresh leaf litter to nibblers on fine roots, to aggressive and lethal colonizers of inner bark tissues. Most Phytophthoras cause root diseases, but on trees especially, some cause lethal stem cankers or even infect leaves. Some species are able to colonize a broad range of plant species, while others are specialized to one or a few host plants [7].

Understanding the "emergence" of Phytophthora species as pathogens of trees requires some knowledge of the ecological milieu from which they are emerging. Phytophthora species are widespread, relatively abundant, very diverse, and poorly understood in many relatively undisturbed forest ecosystems [10]. Research on the ecology of Phytophthora, including biodiversity, epidemiology, and pathogenesis, has focused on a few aggressive pathogens of crop plants and destructive invasive pathogens in forests. Although their behavior in forest ecosystems remains largely unknown, a new appreciation for the ecological amplitude of the genus is emerging.

In recent years, increased attention to the full assemblage of species present in a range of more natural habitats has been evident in the literature, although there remain far more questions than answers. Even in simplified agricultural ecosystems, more than one Phytophthora species may be present, each responding to different environmental cues and presumably interacting with different host genes. In alfalfa, for example, Phytophthora medicaginis exhibits aggressive race $\times$ cultivar pathogenic specificity, whereas the widespread but cryptic Phytophthora megasperma is cultivar nonspecific [11, 12]. It should not be surprising that more complex ecosystems, with diverse communities of plants occupying environmentally distinctive habitats, are home to many Phytophthora species. Forest soil, streams, and the upper canopies of trees around the world are now being explored for Phytophthora diversity [10].

In the mixed evergreen forests of southwest Oregon, for example, the Phytophthora species from plants, soils, and streams have been catalogued. In recent large-scale surveys of forests dominated by tanoak and Douglas-fir, and in riparian alder forests, also in western Oregon, the search for specific invasive species afforded the opportunity to identify the other Phytophthora species present. Different suites of species were present on tree boles, tree canopies, in soil, and in streams. In tanoak forests, 18 species were recorded in addition to the exotic Phytophthora ramorum, target of the surveys [13]. Only P. ramorum (and Phytophthora lateralis where Port-Orford cedar was present) caused disease sufficient to attract attention. Although nine species were isolated from bole cankers on tanoak, all except $P$. ramorum and Phytophthora nemorosa were very infrequent, and the latter affected scattered individual trees with no evidence of epidemic spread. Seven of the nine species recovered from rain traps beneath tanoak canopies were also associated with bole cankers and in roughly the same frequencies. Only P. ramorum behaves as an invasive pathogen in this ecosystem. Different Phytophthora taxa dominated streams. They may be saprophytic in this habitat, or perhaps they maintain their populations through fine-root pathogenesis on streamside vegetation. They were not consistently associated with any disease of riparian vegetation [13].

Species diversity in riparian alder stands in western Oregon was similar to that seen in tanoak forests. Phytophthora species were widespread and diverse [14]. Most sites (83 out of 88 surveyed) yielded Phytophthora species; 20 different species were recovered overall. Only three out of the 20 species recovered from the alder riparian ecosystems were found in all three habitats examined: roots, soil, and water. Twenty-nine different species were identified among 2171 isolates across the two surveys (tanoak and alder), but only 11 species were common to both surveys. 
Of the 29 species identified in these two surveys, only three (P. ramorum, P. lateralis, and $P$. cinnamomi, discussed below) are behaving as emergent species in these ecosystems. Others, Phytophthora nicotianae and Phytophthora syringae, for example, are likely recent introductions to these forest sites, but at this point at least remain rare and non-threatening. The remainder appears to be indigenous, or at least naturalized, in these forests.

Surveys in temperate forests in other parts of the world support these findings, although they usually cover larger, more diverse forested areas and investigate only forest soils or streams [15-26]. Similar numbers of species and many of the same taxa are reported from soils, streams, or trees in the eastern USA and from Europe. Less complete inventories at least suggest that similar results will be obtained for temperate forests in Asia, South America, and South Africa [27-30]. The emerging story of a diverse assemblage and distinctive habitats is the same in Australia, although the species list is quite different [31-33].

In summary Phytophthora species are widespread in wild forests. Three ecological assemblages, or guilds, can be distinguished: (a) aquatic opportunists, (b) foliar pathogens, and (c) soilborne fine-root and canker pathogens [10]. Most species behave as indigenous organisms, coevolved with the forest, or at least naturalized in these habitats. Emerging, invasive species are, however, associated with all three groups. These get most of the attention. Their evolutionary origins are varied, with fine-root pathogens and twig and foliar pathogens among them, highlighting the challenge of predicting invasive potential before the event. It is from the large pool of well-behaved but poorly understood species that the next destructive species will emerge, however.

A number of species have emerged from coevolved obscurity in wildland ecosystems (Table 1). Three examples are now examined in some detail to illustrate the range of pathways to emergence and the varied consequences to forest environments. All are clearly alien to the forests they are presently altering so dramatically, but their epidemiology and their ecological impacts differ widely. Indeed, it is difficult to generalize. P. lateralis causes Port-Orford cedar root disease in western North America. P. ramorum is causing unprecedented mortality in oak and tanoak forests in California, as the cause of sudden oak death, and is killing planted larch in the UK, and Phytophthora cinnamomi kills trees in several parts of the world where it has been introduced, but nowhere more dramatically than in the jarrah eucalyptus forests of Western Australia.

\section{Phytophthora lateralis}

P. lateralis has "emerged" at least three times in the last 80 years, causing dramatic epidemics on Chamaecyparis lawsoniana (Port-Orford cedar or Lawson's cypress) in horticultural nurseries and urban ornamental plantings and rural windbreaks, then in native forests in western North America, and now in European landscape plantings.

P. lateralis is generally thought of as host specific, and all reports of epidemic damage involve $C$. lawsoniana although it is reported from Taxus brevifolia growing in close association with infected C. lawsoniana in forests [34] and with Thuja and other Chamaecyparis species in landscape plantings [35]. Recently, the pathogen was found in Chamaecyparis obtusa forests in Taiwan, although evidence of disease was subtle or lacking $[36,37]$.

The swimming zoospores initiate infection. Zoospores are attracted to young root tips, following gradients of root exudates in water-saturated soils or where roots grow into streams. The pathogen colonizes the root system, killing the inner bark as it progresses [38]. When it reaches the root collar, the tree is girdled and becomes attractive to secondary bark beetles that are often the immediate cause of death. Meanwhile, the pathogen forms thick-walled, resistant chlamydospores in the dead roots which facilitate survival through seasonal dry periods. These resting spores are also transported in soil on dirty equipment to new sites, where they may be activated in the next wet period and initiate new infections [39].

The geographic origin of $P$. lateralis is suspected to be eastern Asia, home to several Chamaecyparis species that are generally tolerant or resistant to infection. An expedition was mounted in 2008 to search for P. lateralis in Taiwan, and the pathogen was recovered by baiting from soil in a healthy old growth C. obtusa stand. A second expedition in 2010 isolated P. lateralis from C. obtusa foliage, suggesting aerial spread, and many more isolates were recovered from soil and foliage $[9 \cdot 37]$.

The horticultural value of $C$. lawsoniana undoubtedly led to the first emergence of $P$. lateralis in North America. More than 100 variant individuals, differing in foliage color and growth form, have been selected in the wild, propagated, named, and entered the horticultural trade [39]. C. obtusa and related species are also in the nursery trade, brought back from Asia by early plant explorers. The pathogen was first noted killing cedars in horticultural nurseries and landscape plantings in Washington state around 1920 and spread quickly through the west coast nursery industry and into landscape plantings of POC [40]. The disease (Port-Orford cedar root disease) nearly eliminated $C$. lawsoniana from the nursery trade and continues to spread in old established ornamental and windbreak plantings throughout western North America.

The second emergence of $P$. lateralis was into the native cedar forest near Coos Bay, Oregon, in about 1950 [41]. It was apparently transported on infested ornamental plants to a nursery adjacent to a forest stand. Once in the forest, the economic value of the cedar assured continued transport of the pathogen 
throughout the tree's range. It was carried in mud, on logging equipment, road maintenance vehicles, and passenger cars along the ever expanding road network. Vehicles took the pathogen uphill, and it washed downhill in the many streams of the region, killing nearly all cedars growing within root reach of water or roads [39]. The resulting epidemic is closely tied to the forest road system and to the streams that are infested as they cross those roads [39, 42-44]. It is estimated that about $10 \%$ of the $C$. lawsoniana growing naturally within its limited native forest range has been killed to date [45].

The impacts of cedar root disease are both ecological and economic. Port-Orford cedar is endemic to mixed conifer forests in southwest Oregon and northwest California [39]. It is normally a riparian species; only in the most fertile soils with relatively high rainfall does it grow away from streams and then it usually grows in mixture with other conifers. It is one of a very few trees in the region that can tolerate the heavy metals in ultramafic soils, however, and across thousands of hectares in the Klamath Mountains, it is the dominant tree. Port-Orford cedar is long-lived, with decay-resistant heartwood and thick, fire-resistant bark at maturity. It becomes increasingly important in late-successional forests. The decay-resistant, straight-grained wood of mature and oldgrowth trees is very valuable, especially on the export market to Asian countries, where it substitutes for native Hinoki Cypress, another Chamaecyparis species that is in short supply in its native Asian range [39].

The third emergence of $P$. lateralis is more recent. It is now established in the European landscape, first in France and the Netherlands [46-48], then in Scotland, England, and northern Ireland $[35,49]$. Aerial infections suggest that, in landscape plantings in Europe especially, it also could spread through airborne sporangia $[48,50]$. Morphological and phylogenetic evidence strongly supports the pathway from an indigenous population in Asia to nurseries and then the forest in North America, and then onward to Europe. The intercontinental trade in ornamental plants is a recurring suspect $[3,6]$.

\section{Phytophthora ramorum}

The emergence of $P$. ramorum as a pathogen of trans-Atlantic concern is more recent, yet origins are evidently complex and remain elusive. People first noticed coast live oak (Quercus agrifolia) and tanoak (Notholithocarpus densiflorus) dying in alarming numbers about 1990, in woodlands and fragmented forests in suburban and rural residential areas near San Francisco, California [51]. It was not until 2000, however, that the causal agent was discovered [52]. An undescribed Phytophthora species, soon to be named P. ramorum, was spreading from tree to tree above ground. Strangely, $P$. ramorum, the sudden oak death pathogen, is a close relative of $P$. lateralis, the cedar pathogen, with the same basic life cycle-swimming zoospores and thick-walled resting chlamydospores - but in this disease, the spores swim in films of water on leaf surfaces and drip from the upper canopy of infected trees onto the main stems where they penetrate and kill the inner bark and sapwood [53].

$P$. ramorum spreads in three distinct ways: spores are splashed up and drip downward in rain; spores produced on infected twigs and leaves are lofted into turbulent air and carried on air currents until they settle out by gravity or are washed out of the air by rain; and it has been transported between states and continents on infected horticultural nursery plants [53, 54]. It is turbulent dispersal of airborne spores that allows $P$. ramorum to spread rapidly across the landscape and the nursery trade that has moved it between countries and continents $[55,56 \bullet \bullet$.

$P$. ramorum also differs from $P$. lateralis in its host range. While $P$. lateralis is host specific, $P$. ramorum infects most of the plant species in western forests [57]. Mortality is most dramatic in the oaks (sudden oak death), but rhododendrons and several other plants in the Ericaceae are damaged (ramorum dieback). A miscellaneous array of plant species are susceptible to a lesser degree, usually suffering only scattered leaf spots (ramorum leaf blight). Rhododendrons and related genera are important in the nursery trade and are implicated in the long-distance spread of the pathogen [56••].

Historic and genetic evidence indicates at least three different "emergence events" in the continuing story of P. ramorum. Its indigenous home is unknown, but fingers are often pointed toward the Himalayan region of Asia. Two related lines of evidence support the hypothesis: the Himalayas are indigenous centers of diversity for Rhododendron as well as oaks and tanoaks [58], and as a consequence, the Himalayas have been destination for many early and contemporary plant explorers. P. ramorum has not yet been found, however, in Asia. Whatever the origin, genetic evidence shows that P. ramorum independently emerged in Europe and on the west coast of North America [56••]. These two genetically distinct lineages then spread in the nursery trade across Europe and throughout North America. Damage to nursery stock is minimal and easily managed, however. It was only when the pathogen spread to forests in California and then Oregon [53], and to historic gardens and woodlands in England, that it became destructive.

In North America, tanoak is the most susceptible tree, but the native myrtlewood, Umbellularia californica, harbors the pathogen without suffering serious damage itself, while supporting abundant production of spores which drive the epidemic in California [42, 59]. It appears at this point that tanoak will be practically eliminated from northern and western portions of its range in California and Oregon.

The economic value of tanoak over the several million hectares of California and Oregon woodland at greatest risk is very low. On lands managed for timber production, it is considered a competitor with the much more desirable 
conifers Douglas-fir and redwood. Dead, however, tanoak becomes a fire risk, in a region already prone to fire. The cost of tree removal to reduce fire risk and the physical hazard of falling trees is a financial burden to landowners. The tree produces acorns, and some animals and insects are dependent on this food source. The larger ecological importance of tanoak depends on the composition of the forest community where it is growing and the successional stage of the stand.

Tanoak is an early successional species, colonizing quickly after stand replacing disturbance such as wildfire or timber harvest. It sprouts prolifically from stumps. Sudden oak death, however, kills many of the sprouts as well. On many sites, tanoak is naturally overtopped by Douglas-fir and redwood in time and becomes a less important part of the stand in late successional forests. In other areas, there are extensive areas of nearly pure tanoak forest, usually following large wildfires, and loss of tanoak may force an extended period of chaparral vegetation. Tanoak also grows in mixture with other hardwoods, which in many situations will simply expand their crowns as the tanoak is killed, continuing the forest type, minus one species.

The third emergence of $P$. ramorum is really an extension of the original introduction into England, but it was so unexpected and destructive as to warrant special discussion. It also illustrates the still unpredictable danger of emergent pathogens. In 2010, P. ramorum was reported killing larch trees in England and Wales [60]. It was quickly tracked up the west coast of Great Britain damaging many larch plantations and leading to the preemptive harvest of many more. Although larch had previously been shown to be very susceptible in seedling inoculation tests with the North American lineage of the pathogen [57], the risk was not taken seriously because the natural and commercial range of larch in North America was in drier ecosystems where Phytophthora was not considered a serious threat.

\section{Phytophthora cinnamomi}

P. cinnamomi is the third of our infamous exemplars of emergent pathogens, with the longest record of ecological destruction. Today, it is killing a wide range of woody plants in warm temperate forests and wildlands in Australia, southern Africa, warmer parts of North America, and Europe [7]. Its origins are still unknown, although speculation centers on Taiwan and the islands of Southeast Asia and the Pacific [61, 62]. It was apparently first carried around the world on sailing ships, in roots and soil of exotic plants gathered by collectors for the estates and public gardens of the New and Old Worlds [61]. It is soilborne like P. lateralis, but with a very broad host range. It destroyed the southern chestnut forest in the USA before chestnut blight, caused by an ascomycete (Kingdom Fungi), another alien invader arriving from the north, finished the job
[63]. One hundred years later, it reemerged in the southeastern USA as cause of littleleaf disease, a debilitating decline of shortleaf pine (Pinus echinata) colonizing former agricultural sites degraded by decades of cotton farming [64]. Today, $P$. cinnamomi is naturalized in much of the southeastern US forest. The most susceptible forest species are gone; the pathogen persists as a widespread sublethal root nibbler. There is some evidence that it is advancing northward with warming climates [18].

In southern Europe, P. cinnamomi is causing widespread collapse of cork oak woodlands as it is transported across the landscape in agroforestry operations [65], and in Australia, it is considered one of the five most destructive environmental threats facing that continent [66]. While it kills some species of eucalyptus trees and other plants in scattered areas of temperate forest throughout Australia [66], it is most destructive in Western Australia where it threatens the jarrah eucalyptus/ Banksia forest and woodlands, as well as the expansive heathlands with their rich flora of rare Gondwanaland endemics $[66,67]$.

The introduction of $P$. cinnamomi to Australia is lost in time. It was already widespread, and local damage was extensive before it was identified as the cause of "jarrah dieback" in 1964. It was another 8 years before it was accepted that this was an exotic pathogen, not a native species gone "wild" in a disturbed environment [66]. The epidemic was and is closely associated with humans and their activities in the bush, especially mining exploration, forest harvest, and recreation. The aftermath is regularly a dramatically altered, and usually degraded, plant community. In the jarrah, for example, the Banksia species are especially susceptible and die first. The increase in inoculum from Banksia infection overcomes the jarrah. Xanthoria, the grass tree in the Lily family, is killed, as are most of the other shrub species and many herbs. The residual community is often dominated by grasses and sedges [67].

P. cinnamomi is already in most conducive forest ecosystems around the world. New emergence episodes are associated with local transport, as along tracks in Australia, or with warming forest environments allowing the slow advance of the pathogen evident in Europe, California woodlands, and eastern North American oak forests [68-70].

\section{Other Emerging Phytophthoras}

Many Phytophthora species have been moved around the world to new forest environments where they have become invasive [1]. Other species, less well documented, have emerged from obscurity in their lands of origin and assumed destructive roles as climate or disturbance regimes change. The following selected examples illustrate the variety of circumstances that can transform a Phytophthora species into an 
economic or environmental threat, as well as the limits in many cases to our understanding of pathogen emergence.

Phytophthora pluvialis is the most recent addition to this list of emerging Phytophthora species. It was discovered by accident in rain traps in western Oregon forests, not associated with any dramatic disease [71]. Then, it was reported as the cause of red needle cast, a new defoliating disease of radiata pine and Douglas-fir in New Zealand [72]. Both trees are widely planted, economically valuable species exotic to New Zealand. It was probably accidentally introduced to New Zealand, where it found a conducive environment and a new host and has become a pest of concern.

"Mal del cipres," cypress decline in the Patagonian Andes, was a lethal disease of increasing concern in Argentina, first reported in 1948 but of unknown cause until Phytophthora austrocedrae was described in 2007 [73]. The pathogen appears to have been introduced on forest tree seedlings imported from around the world for an experimental nursery and to have been spread from there on nursery stock. It now threatens the few, and mostly rare, native Cupressaceae in South America. Alarmingly, the pathogen recently emerged in Scotland, killing native junipers [74]. Again, it was probably transported on nursery stock.

All Phytophthora introductions do not lead to epidemics, fortunately. Phytophthora kernoviae perhaps represents a failed emergence. It was recently described from horticultural display gardens in southwestern England, apparently introduced on nursery stock at about the same time as the emergence of P. ramorum in England [75]. But unlike the $P$. ramorum story, $P$. kernoviae, while established now in gardens and woodlands, has caused little damage. It is one of the few invasive Phytophthoras whose origin is reasonably well established. It is resident in New Zealand forest soils, with collections going back at least to 1951 . The only reports of disease, however, are from an abandoned orchard of Annona cherimoya, the custard apple [76]. Recently, there are reports of $P$. kernoviae from forests in Chile. Perhaps it is more widely distributed in the Gondwanan ecosystems of the southern hemisphere [77].

One of the most disturbing newly emergent Phytophthora species is the still informally described $P$. taxon agathis. It kills the massive and iconic kauri trees (Agathis australis) in New Zealand. Its origin is unknown, but it is now spreading along walking tracks routed to admire, or worship, these culturally significant trees [72].

Phytophthora alni represents yet another path to emergence as a devastating forest pathogen. The evolutionary history of this species includes a series of hybridization events resulting in a new species with previously unprecedented pathogenicity to alder trees $[78,79]$. It was first recognized in England [80], but with awareness came reports from rivers throughout Europe, and through the nursery trade again, it has been spread into forest stands away from riparian areas [81].
Our last example is Phytophthora pinifolia, cause of the most explosive emergence of a forest pathogen on record. In 2004, unusual disease symptoms were observed in radiata pine plantations in central Chile [82]. By 2006, 60,000 ha were red, and the year following, the epidemic was collapsing. Today, symptoms are seen on scattered trees and the disease is no longer causing significant defoliation. It is not known where the pathogen came from, or what triggered its outbreak, or its collapse.

\section{Conclusions}

These examples of emerging Phytophthora diseases in forests have in common the unique life cycle of these water molds. At the same time, they illustrate the very different pathways microbes can take from innocuous indigenous organisms to emergence as ecosystem altering invasive pathogens. Their impacts on the ecosystem are also very different, depending on the host range of the pathogen and the place of the host tree in the forest community.

Phytophthora diseases are important targets of efforts to protect the ecological and economic values of forests. An early, and ongoing, example of the complexity of disease management against an emerged pathogen is provided by the Port-Orford cedar root disease control program coordinated in federal forests in Oregon and California by the USDA Forest Service [45]. It is integrated into all forest land management activities on National Forests in areas where cedar grows. The goals are straightforward: maintain the values of Port-Orford cedar in its native range by protecting the remaining uninfested areas and restoring cedar in stands already altered by $P$. lateralis. The strategy has three parts: (1) stop the spread, (2) reduce inoculum levels, and (3) restore the cedar. Tactics are varied and applied on a site-specific basis after a risk analysis. They include in part 1 , road closures and washing vehicles before entering healthy forests and reducing inoculum by killing small vulnerable Port-Orford cedar in disturbed roadside soil to reduce the opportunity for disease increase [83]. A feature of the management strategy is a program to select for resistance in the surviving Port-Orford cedar population and to plant disease-resistant seedlings in the forest [84, 85].

Management actions against sudden oak death follow the same tripartite strategy of stopping spread, reducing inoculum, and restoring degraded forests [53]. Different parts of the program are emphasized in different regions. There is a national and international quarantine and certified plant inspection program evolving to cut off pathways of spread through the nursery trade [86]. In Oregon, the effort is to slow the spread by eradication of new spot infections before they in turn become sources of inoculum [87]. Intensive survey and monitoring, including regular aerial reconnaissance, is used to detect early 
infections, and infected trees are cut and burned, hopefully before inoculum is produced and spreads further. The Oregon eradication program has not eliminated the pathogen, but it has had a demonstrable effect on slowing the epidemic.

Further south in California, where the disease is already established, the situation is more discouraging. Most effort is going into managing the aftermath of the epidemic, especially through fuels reduction, and restoring forest cover by planting disease-tolerant species [88]. Programs to identify resistant oaks and tanoak are also beginning.

Some of the most dramatic and effective programs to manage an invasive forest pathogen are ongoing in Western Australia, directed against $P$. cinnamomi. One important tool is the oomycete-specific fungicide phosphonate [89]. This compound stimulates host resistance to the pathogen. Phosphonate injected into the trunks of susceptible trees provides 4 or 5 years of protection against subsequent infection by the pathogen [89]. Regular programs of injection are organized by volunteers in many areas to protect trees in parks and local natural areas. Phosphonate is also applied from airplanes to protect susceptible vegetation in national parks and other wildlands.

ALCOA Aluminum Company has institutionalized a voluntary, integrated "dieback management plan" on their lease holdings in Western Australia [90]. ALCOA strip mines the lateritic soils for bauxite ore, then restores the land to its native vegetation. The challenge is enormous given the scale of their operation and the nature of strip mining. They have been largely successful through a program that includes mapping infested areas before any activity takes place. Equipment never passes from infested areas into clean areas without washing. Overburden from infested areas is stored separately from clean soil and only returned to mined-out sites that were previously infested. Dieback sanitation regulations are monitored and enforced by the company [90].

Active programs are underway with each of these pathogens to manage, if not eliminate, their damage. In no case, however, has eradication after establishment been achieved. Prevention, by blocking initial introduction, has the highest probability of success, but once the beachhead is secured by a new pathogen, the odds of stopping it increase rapidly. "Fight them on the beaches, or let the new order begin!" Professor Hal Mooney of Stanford University was referring to invasive plants when he delivered this rallying cry, but it applies to invasive pathogens as well [1]. The "new order" of degraded ecosystems that often result from emergent Phytophthora species is too much with us already.

\section{Compliance with Ethics Guidelines}

Conflict of Interest Dr. Hansen has no conflicts of interests to declare.

Human and Animal Rights and Informed Consent This article does not contain any studies with human or animal subjects performed by the author.

\section{References}

Papers of particular interest, published recently, have been highlighted as:

- Of importance

• Of major importance

1. Hansen EM. Alien forest pathogens: phytophthora species are changing world forests. Boreal Environ Res. 2007;13:33-41.

2. Boyd IL, Freer-Smith PH, Gilligan CA, Godfray HCJ. The consequence of tree pests and diseases for ecosystem services. Science. 2013;342(6160):1235773.

3. Santini A, Ghelardini L, De Pace C, Desprez-Loustau ML, Capretti $\mathrm{P}$, Chandelier A, et al. Biogeographical patterns and determinants of invasion by forest pathogens in Europe. New Phytol. 2013;197(1): 238-50.

4. Hansen EM, Goheen E. Phellinus weirii and other native root pathogens as determinants of forest structure and process in western North America. Annu Rev Phytopathol. 2000;38:515-39.

5. Liebhold AM, Brockerhoff EG, Garrett LJ, Parke JL, Britton KO. Live plant imports: the major pathway for forest insect and pathogen invasions of the US. Front Ecol Environ. 2012;10(3):135-43.

6. Erwin D, Ribeiro O. Phytophthora diseases worldwide. St. Paul: APS Press; 1996. 562p.

7. Barr DJS. Evolution and kingdoms of organisms from the perspective of a mycologist. Mycologia. 1992;84:1-11.

8. Gunderson JH, Elwood H, Ingold A, Kindle K, Sogin ML. Phylogenetic relationship between chlorophytes, chrysophytes, and oomycetes. Proc Natl Acad Sci U S A. 1987;84:5823-7.

9. Hansen EM, Reeser P, Sutton W. Phytophthora beyond agriculture. Annu Rev Phytopathol. 2012. doi:10.1146/annurev-phyto-081211172946. Most recent review of Phytophthora in natural ecosystems.

10. Hansen EM, Brasier CM, Shaw DS, Hamm PB. The taxonomic structure of Phytophthora megasperma: evidence for emerging biological species groups. Trans Br Mycol Soc. 1986;87:557-73.

11. Hansen EM, Maxwell DP. Species of the Phytophthora megasperma complex. Mycologia. 1991;83:376-81.

12. Reeser PW, Sutton W, Hansen EM, Remigi P, Adams GC. Phytophthora species in forest streams in Oregon and Alaska. Mycologia. 2011;103:22-35.

13. Sims L, Sutton W, Reeser P, Hansen E. The Phytophthora species assemblage and diversity in riparian alder ecosystems of western Oregon, USA. Mycologia submitted.

14. Balci Y, Balci S, Eggers J, Juzwik J, Long R, MacDonald W, et al. Phytophthora species associated with forest soils in eastern and north central U. S. oak ecosystems. Plant Dis. 2007;91:705-10.

15. Balci Y, Halmschlager E. Incidence of Phytophthora species in oak forests in Austria and their possible involvement in oak decline. For Pathol. 2003;33:157-74.

16. Balci Y, Halmschlager E. Phytophthora species in oak ecosystems in Turkey and their association with declining oak trees. Plant Pathol. 2003;52:694-702.

17. Balci Y, Long RP, Mansfield M, Balser D, MacDonald WL. Involvement of Phytophthora species in white oak (Quercus alba) decline in southern Ohio. For Pathol. 2010;40:430-42.

18. Hwang J, Jeffers SN, Oak SW. Occurrence and distribution of Phytophthora pseudosyringae in forest streams of North Carolina. Phytopathology. 2007;97:S49.

19. Hwang J, Oak SW, Jeffers SN. Variation in population density and diversity of Phytophthora species in streams within a forest watershed. Phytopathology. 2008;98:S70. 
20. Jung T, Blaschke H, Neumann P. Isolation, identification and pathogenicity of Phytophthora species from declining oak stands. Eur J For Pathol. 1996;26:253-72.

21. Jung T, Hansen EM, Winton L, Osswald W, Delatour C. Three new species of Phytophthora from European oak forests. Mycol Res. 2002;106:397-411.

22. Jung T, Blaschke H, Osswald W. Involvement of Phytophthora species in Central European oak decline and the effect of site factors on the disease. Plant Pathol. 2000;49:706-18.

23. Jonsson U, Lundberg L, Sonesson K, Jung T. First records of soilborne Phytophthora species in Swedish oak forests. For Pathol. 2003;33:175-9.

24. Vettraino AM, Barzanti GP, Bianco MC, Ragazzi A, Capretti P, Paoletti E, et al. Occurrence of Phytophthora species in oak stands in Italy and their association with declining oak trees. For Pathol. 2002;32:19-28.

25. Vettraino AM, More O, Perlerou C, Robin C, Diamandis S, Vannini A. Occurrence and distribution of Phytophthora species in European chestnut stands, and their association with ink disease and crown decline. Eur J Plant Pathol. 2005;111:169-80.

26. Greslebin A, Hansen EM, Winton LM, Rachenberg M. Phytophthora species from soil and streams of declining Austrocedrus chilensis forests in Patagonia, Argentina. Mycologia. 2005;97:218-28.

27. von Broembsen S. Distribution of Phytophthora cinnamomi in rivers of the southwestern Cape Province. Phytophylactica. 1984;16: 227-9.

28. Huai W-X, Tian G, Hansen EM, Zhao W-x, Goheen EM, Grünwald $\mathrm{NJ}$, et al. Identification of Phytophthora species baited and isolated from forest soil and streams in northwestern Yunnan province. China For Path. 2013;43:87-103. doi:10.1111/efp.12015.

29. Oh E, Gryzenhout M, Wingfield BD, Wingfield MJ. Phytophthora species from stream water in South Africa. In Abstracts: 5th IUFRO Phytophthoras in forests and natural ecosystems, Rotura, New Zealand, p. 27. http://www.scionresearch.com/_data/assets/pdf_ file/0014/33341/Abstracts Phyto2010.pdf (2010).

30. Burgess TI, Webster JL, Ciampini JA, White D, Hardy GE, Stukely MJC. Re-evaluation of Phytophthora species isolated during 30 years of vegetation health surveys in western Australia using molecular techniques. Plant Dis. 2009;93:215-23.

31. Jung T, Stukely MJC, Hardy GESJ, White D, Paap T, Dunstan WA, et al. Multiple new Phytophthora species from ITS Clade 6 associated with natural ecosystems in Australia: evolutionary and ecological implications. Persoonia. 2011;26:13-39.

32. Smith BW, Smith IW, Cunnington J, Jones RH. An evaluation of stream monitoring techniques for surveys for Phytophthora species in Victoria, Australia. Proceedings of the 4th meeting of the IUFRO Working Party S07.02.09: Phytophthoras in forests and natural ecosystems. Gen. Tech Rep PSW-GTR-221. Albany, CA: USDA Forest Service, PSW Research; 2009. p. 325.

33. Murray M, Hansen EM. Susceptibility of Pacific yew to Phytophthora lateralis. Plant Dis. 1997;81:1400-4.

34. Green S, Brasier CM, Schlenzig A, McCracken A, MacAskill GA, Wilson M, et al. The destructive invasive pathogen Phytophthora lateralis found on Chamaecyparis lawsoniana across the UK. For Pathol. 2013;43(1):19-28.

35. Brasier CM, Vettraino AM, Chang TT, Vannini A. Phytophthora lateralis discovered in an old growth Chamaecyparis forest in Taiwan. Plant Pathol. 2010;59(4):595-603.

36. Webber JF, Vettraino AM, Chang TT, Bellgard SE, Brasier CM, Vannini A. Isolation of Phytophthora lateralis from Chamaecyparis foliage in Taiwan. For Pathol. 2011;42(2):136-43.

37. Oh E, Hansen EM. Histopathology of infection and colonization of susceptible and resistant Port-Orford-cedar by Phytophthora lateralis. Phytopathology. 2007;97:684-93.
38. Hansen EM, Goheen DJ, Jules ES, Ullian B. Managing PortOrford-cedar and the introduced pathogen Phytophthora lateralis. Plant Dis. 2000;84:4-14.

39. Zobel DB, Roth LF, Hawk GM. Ecology, pathology, and management of Port-Orford-cedar (Chamaecyparis lawsoniana). U.S.D.A. Forest Service, Pacific Northwest Forest and Range Experiment Station, General Technical Report PNW-184; 1985.

40. Tucker CM, Milbrath JA. Root rot of Chamaecyparis caused by a species of Phytophthora. Mycologia. 1942;34:94-101. 94. 96.

41. Roth LF, Trione EJ, Ruhmann WH. Phytophthora induced root rot of native Port-Orford-cedar. J For. 1957;55:294-8.

42. Clark WC. Road networks, timber harvest and the spread of Phytophthora root rot. MS Thesis. Oregon State University. https://ir.library.oregonstate.edu/xmlui/bitstream/handle/1957/ 23622/ClarkWilliamC2011.pdf?sequence=1 (2011).

43. USDA-FS, USDI-BLM. A range-wide assessment of Port-Orfordcedar (Chamaecyparis lawsoniana) on federal lands, page 182, $\mathrm{P}$. Oregon/Washington State Office, OR, ed. http://www.fs.usda.gov/ Internet/FSE_DOCUMENTS/stelprdb5316517.pdf (2003).

44. Jules ES, Kauffman MJ, Ritts WD, Carroll AL. Spread of an invasive pathogen over a variable landscape: a nonnative root rot on Port Orford cedar. Ecology. 2002;83318(11):3167-81.

45. USDA-FS. USDI-BLM. Final supplemental environmental impact statement-management of Port-Orford-cedar in southwest Oregon, Portland OR. http://www.fs.fed.us/r6/rogue-siskiyou/ projects/foresthealth/poc-seis.shtml (2004) 485 p.343 18 .

46. Hansen EM, Streito C, Delatour C. First confirmation of Phytophthora lateralis in Europe. Plant Dis. 1999;83:587.

47. Meffert JP. First record of Phytophthora lateralis in the Netherlands. http://www.minlnv.nl/cdlpub/servlet/CDLServlet?p_file_id=19844 (2007).

48. Robin C, Piou D, Feau N, Douzon G, Schenck N, Hansen EM. Root and aerial infections of Chamaecyparis lawsoniana by Phytophthora lateralis: a new threat for European countries. For Pathol. 2011;41(5):417-24.

49. Brasier CM, Franceschini S, Vettraino AM, Hansen EM, Green S, Robin C, et al. Four phenotypically and phylogenetically distinct lineages in Phytophthora lateralis. Fungal Biology. 2012;116(12): $1232-49$.

50. Trione EJ, Roth LF. Aerial infection of Chamaecyparis by phytophthora lateralis. Plant Dis Report. 1957;41:211-5. 337.

51. Rizzo DM, Garbelotto M, Davidson JM, Slaughter GW. Phytophthora ramorum as the cause of extensive mortality of Quercus spp. and Lithocarpus densiflorus in California. Plant Dis. 2002;86:205-14.

52. Werres S, Marwitz R, Man In't Veld WA, De Cock AWAM, Bonants PJM, De Weerdt M, et al. Phytophthora ramorum sp. nov., a new pathogen on Rhododendron and Viburnum. Mycol Res. 2001;105:1155-65.

53. Rizzo DM, Garbelotto M, Hansen EM. Phytophthora ramorum: Integrative research and management of an emerging pathogen in California and Oregon forests. Annu Rev Phytopathol. 2005;43: 309-45.

54. Hansen EM, Kanaskie A, Prospero S, McWilliams M, Goheen EM, Osterbauer N, et al. Epidemiology of Phytophthora ramorum in Oregon tanoak forests. Can J For Res. 2008;38:1133-43.

55. Goss EM, Carbone I, Grünwald NJ. Ancient isolation and independent evolution of the three clonal lineages of the emerging sudden oak death pathogen Phytophthora ramorum. Mol Ecol. 2009;18:1161-74.

56.• Grünwald NJ, Garbelotto M, Goss EM, Heungens K, Prospero S. Emergence of the Sudden Oak Death pathogen Phytophthora ramorum. Trends Microbiol. 2012;20:131-8. Most recent summary of long-distance spread of P. ramorum based on population genetics.

57. Hansen EM, Parke JL, Sutton W. Susceptibility of Oregon forest trees and shrubs to Phytophthora ramorum: a comparison of artificial inoculation and natural infection. Plant Dis. 2005;89:63-70. 
58. Vavilov NI. 1951. The origin, variation, immunity and breeding of cultivated plants. (Translated from Russian by K. S. Chester.) New York: Ronald Press Co. Bot. Bull. Acad. Sin. (1996) 37: 165-171.

59. Malony PE, Lynch SC, Kane SF, Jensen CE, Rizzo DM. Establishment of an emerging generalist pathogen in redwood forest communities. J Ecol. 2005;93:899-905.

60. Brasier CM, Webber JL. Plant pathology: sudden larch death. Nature. 2010;466:824-5.

61. Zentmeyer GA. Origin and distribution of four species of Phytophthora. Trans Br Mycol Soc. 1988;91:367-79.

62. Chang TT, Wang WW, Yang WY. RAPD markers for detection of variation in Phytophthora cinnamomi in Taiwan. Bot Bull Acad Sin. 1996;37:165-71.

63. Crandall BS, Gravatt GF, Ryan MM. Root disease of Castanea species and some coniferous and broadleaf nursery stocks, caused by Phytophthora cinnamomi. Phytopathology. 1945;35:162-80.

64. Roth ER. Spread and intensification of the littleleaf disease of pine. J For. 1954;52:592-6.

65. Brasier CM, Robredo F, Ferrez JFP. Evidence for Phytophthora cinnamomi involvement in Iberian oak decline. Plant Pathol. 1993;42:140-5. doi:10.1111/j.1365-3059.1993.tb01482.x.

66. Cahill DM, Rookes JE, Wilson BA, Gibson L, McDougall KL. Phytophthora cinnamomi and Australia's biodiversity: impact, predictions and progress towards control. Aust J Bot. 2008;56:279310.

67. Newhook FJ, Podger FD. The role of Phytophthora cinnamomi in Australian and New Zealand forests. Annu Rev Phytopathol. 1972;10:299-326.

68. Weste G. Impact of Phytophthora species on native vegetation of Australia and Papua New Guinea. Australas Plant Pathol. 1994;23: 190-209.

69. Brasier CM, Scott JK. European oak decline and global warming: a theoretical assessment with special reference to the activity of Phytophthora cinnamomi. EPPO Bull. 1994;24:221-32.

70. Desprez-Loustau M-L, Robin C, Reynaud G, Déqué M, Badeau V, Piou D, et al. Simulating the effects of a climate-change scenario on the geographical range and activity of forest-pathogenic fungi. Can J Plant Pathol. 2007;29:101-20.

71. Meadows IM, Jeffers SN. Distribution and recovery of Phytophthora cinnamomi in soils of mixed hardwood-pine forests of the south-eastern USA. N Z J For Sci. 2011;41:S39-47.

72. Reeser PW, Sutton W, Hansen EM. Phytophthora pluvialis, a new species from mixed tanoak-Douglas-fir forests of western Oregon U.S.A. N Am Fungi. 2013;8(7):1-8. doi:10.2509/naf2013.008.007.

73. Scott $P$, Williams N. Phytophthora diseases in New Zealand forests. N Z J For. 2014;59(2):14-21.

74. Greslebin A, Hansen EM, Sutton W. Phytophthora austrocedrae sp. nov., a new species associated with Austrocedrus chilensis mortality in Patagonia (Argentina). Mycol Res. 2007;111:308-16.

75. Green S, Elliot M, Armstrong A, Hendry SJ. Phytophthora austrocedrae emerges as a serious threat to juniper (Juniperus communis) in Britain. Plant Pathol. 2014. doi:10.1111/ppa.1225.

76. Brasier CM, Beales PA, Kirk SA, Denman S, Rose J. Phytophthora kernoviae sp. nov., an invasive pathogen causing bleeding stem lesions on forest trees and foliar necrosis of ornamentals in the UK. Mycol Res. 2005;109:853-9.
77. Ramsfield TD, Dick MA, Beever RE, Horner IJ, McAlonan MJ, Hill CF. Phytophthora kernoviae in New Zealand Goheen EM, Frankel SJ. Phytophthoras in forests and natural ecosystems. 2009; General Technical Report PSW-GTR-221:47-53.

78. Sanfuentes EA, Fajardo SN, Sabag MA, Hansen EM, Gonzalez MG. Phytophthora kernoviae detection in Drimys winteri (Winter's Bark) forest of southern Chile. In Phytophthoras in forests and natural ecosystems. Abstracts of the 7th Meeting of the IUFRO Working Party S07.02.09. Esquel Argentina. p.45. http://www. iufrophytophthora2014.org/downloads/proceedings.pdf (2014).

79. Brasier CM, Kirk SA, Delcan J, Cooke DEL, Jung T, Man in't Veld WA. Phytophthora alni sp.nov. and its variants: designation of emerging heteroploid hybrid pathogens spreading on Alnus trees. Mycol Res. 2004;108:1172-84.

80. Ioos R, Andrieux A, Marçais B, Frey P. Genetic characterization of the natural hybrid species Phytophthora alni as inferred from nuclear and mitochondrial DNA analyses. Fungal Genet Biol. 2006;43: 511-29.

81. Brasier CM, Rose J, Gibbs JN. An unusual Phytophthora associated with widespread alder mortalityin Britain. Plant Pathol. 1995;45: 999-1007.

82. Jung T, Blaschke M. Phytophthora root and collar rot of alders in Bavaria: distribution, modes of spread, and possible management strategies. Plant Pathol. 2004;53:197-20862.

83. Durán A, Gryzenhout M, Slippers B, Ahumada R, Rotella A, Flores F, et al. Phytophthora pinifolia sp. nov. associated with a serious needle disease of Pinus radiata in Chile. Plant Pathol. 2008;57:71527.

84. Goheen DJ, Mallams K, Betlejewski F, Hansen EM. Effectiveness of vehicle washing and roadside sanitation in decreasing spread potential of Port-Orford-cedar root disease. West J Appl For. 2012;27:170-5.

85. Oh E, Hansen EM, Sniezko RA. Port-Orford-cedar resistant to Phytophthora lateralis. For Pathol. 2006;36:385-94.

86. Sniezko RA, Hamlin J, Hansen EM. Operational program to develop Phytophthora lateralis-resistant populations of Port-Orford-cedar (Chamaecyparis lawsoniana). Pages 65-79. In: Proceedings of the 4th International Workshop on Genetics of Host-Parasite Interactions in Forestry, Eugene Oregon, Palmieri, K.M., tech. coords. Gen. Tech. Rep. PSWGTR-240. Albany, CA: U.S. Department of Agriculture, Forest Service, Pacific Southwest Research Station; 2012.

87. Brasier CM. The biosecurity threat to the UK and global environment from international trade in plants. Plant Pathol. 2008;57:792-808.

88. Peterson EK, Hansen EM, Kanaskie A. Temporal epidemiology of sudden oak death in Oregon. Phytopathology. 2015; 105 :submitted.

89. Cobb RC, Rizzo DM, Hayden KJ, Garbelotto M, Filipe JAN, Gilligan CA, et al. Biodiversity conservation in the face of dramatic forest disease: an integrated conservation strategy for Tanoak (Notholithocarpus densiflorus) threatened by sudden oak death. Madrono. 2013;60:151-64. doi:10.3120/0024-9637-60.2.151.

90. Colquhoun IJ, Hardy GESJ. Managing the risks of phytophthora root and collar rot during bauxite mining in the eucalyptus marginata (Jarrah) forests of Western Australia. Plant Dis. 2000;84:116-27. 